\title{
Analysis of The Impact of Industrial Activities Towards River Vacancy Viewed from BODS, CODS, and TSS Using The QUAL2KW Software Method Approach (Case Study: Klampok River, Semarang District)
}

\author{
Nurandani Hardyanti, Winardi D Nugraha, Vito Edgar S B* \\ Environmental Engineering Department, Faculty of Engineering, Diponegoro University, Semarang, \\ 50275, Indonesia
}

\begin{abstract}
The industrial sector is one of the important sector in supporting the development of a region. Utilization of land around the river that is used for industrial activities will affect the quality of river water. The river can be polluted by waste personinating from industries that operating around the river. The catchment area that used for industry, agriculture, urban development, and the use of land for making roads (gravel or footpaths) can affect the flow of surface water and sediments that it brings to the river. Waste generated from industrial activities can pollute rivers which are a source of water for daily needs and affect the development of biota in them. This can affect river water quality
\end{abstract}

Keywords. industry, river, water, waste, pollute

\section{Introduction}

Water is an important component of the environment for life and life both for humans, flora, fauna and other living things. According to Wardhana (2004) there would be no life if there were no water on earth. River water has the function as a parallel for human life and livelihood as a source of drinking water, irrigation, fisheries and so forth. These human activities cause rivers to become vulnerable to water pollution. Likewise, industrial growth can cause impacts on environmental quality.

BOD, COD, and TSS parameters are indicators of water pollution. High concentrations of BOD, COD, and TSS in river water are caused by the discharge of waste from industrial activities around the Klampok River. According to Metcalf and Eddy (1979) Personanic waste material is quite dominant in the food/beverage processing industry. Personanic materials are composed of carbon, hydrogen, oxygen and some contain nitrogen compounds. Personanic waste is generally in the form of waste that can rot or be degraded

\footnotetext{
*Corresponding author: vitoedgar19@gmail.com
} 
by micropersonanisms, so that when discharged into the water will increase BOD. Discharge of river water polluted by sewage from industrial activities operating around the Klampok River is closely related to the concentration of river water COD parameters on seasonal differences. COD concentrations in the dry season are higher than at the end of the rainy season due to the small influence of river water discharge. TSS is a physical property of water related to turbidity. According Effendi (2003) TSS content in river water is not toxic but if excessive causes turbidity and prevents the entry of sunlight into the waters and affects the process of photosynthesis in river water. River water will give a bad influence on fisheries if the TSS value in river water is too high.

The industrial sector is one of the important sectors in the development of a region. Industry is considered capable of opening jobs for unemployed workers, encouraging the growth of technology that is useful for human life, fostering various interrelated activities in the industrial network so that it is able to function as a driver for development.

\section{Methodology}

\subsection{Sampling Location}

This research was conducted at seven points in segment 5 of the Klampok River that have been determined between points 4 and 5 of the Klampok River, which are located in Jimbaran Village, Pakopen Village, and Sidomukti Village in Bandungan District. Doplang Village, Lemahireng Village, Harjosari Village, Samban Village, and Poncoruso Village Bawen District. Bergas Lor Village, Bergas Kidul Village, Randugunting Village, Jatijajar Village, Diwak Village, Diwak Village, Ngempon Village, Karangjati Village, Bergas District and Derekan Village, Klepu Village, Pringapus District, Semarang Regency. Industries that are sampled are PT. ABC, PT. DEF, and PT. GHI. Sampling was carried out on March 19, 2020. The method used in primary data collection is by sampling at predetermined sampling points and analyzing BOD, COD, and TSS parameters in laboratories as well as measuring cross-section and flow velocity of industrial outlets and creeks, while secondary data is drawn from data sourced from various information, literature, or other sources related to water quality and river capacity. 


\section{Results and Discussion}

\subsection{Segmentation and Identification of Pollutant Sources}

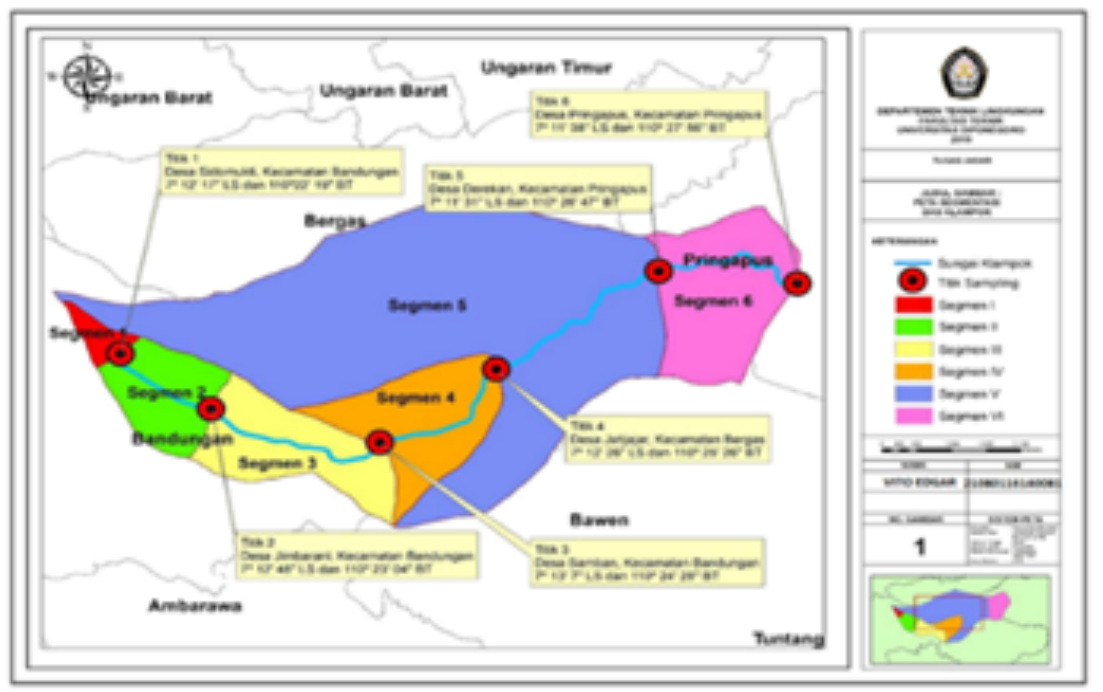

Fig. 1. Klampok River Segmentation

River segmentation functions to make it easier to examine pollutant inputs that enter into each river segment. Klampok River which has a length of $16,063 \mathrm{~km}$ with reference to the Minister of Environment Regulation No. 1 of 2007 concerning Technical Guidelines for Establishing Water Classes, segmentation of water bodies is carried out based on several considerations, namely the use of water (current and future), regional topography, river morphology, potential water sources, potential pollutant sources, and administrative boundaries are then divided into 6 segments.

\subsection{Klampok River Water Quality Analysis for BOD, COD and TSS Parameters}

\subsubsection{BOD Concentration}

Based on the BOD test data it can be seen that the highest BOD concentration is at sampling point 7 which is located after the outlet of PT. GHI is equal to $3.86 \mathrm{mg} / 1$. Sampling point 7 has the highest concentration because it is a mixing point from all sampling points, besides mixing from several previous activities such as agriculture and settlement so that runoff water containing pesticides from rice fields and domestic waste produced by residents in settlements is the cause of the high BOD concentration values. Runoff from agriculture can increase the entry of excess nutrients such as nitrogen and phosphorus and other personanic materials which cause low dissolved oxygen (DO) values that are useful for aquatic ecosystem life and high levels of BOD, COD and colitinjaous bacteria. (Salim, 2002: 107). 


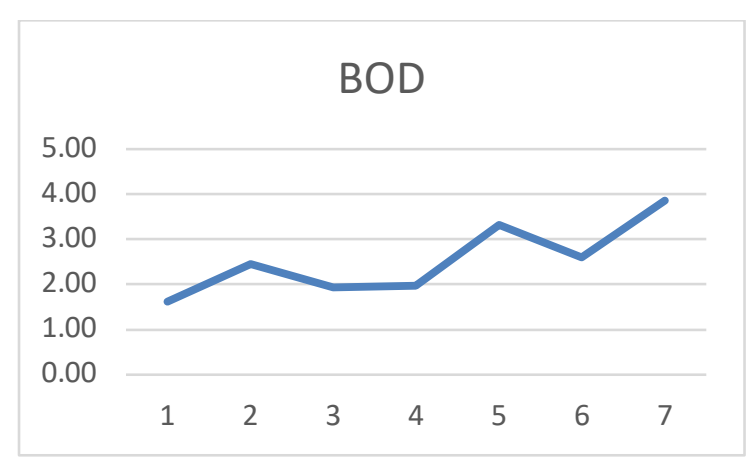

Fig. 2. Concentration BOD Graphic

\subsubsection{COD Concentration}

Based on the COD test data, it can be seen that the COD concentrations at points 1,4 , and 6 do not meet the specified quality standard of $100 \mathrm{mg} / 1$, Points 1, 4, 7 are the points of all industrial outlets studied. The high COD parameters are due to several factors, including the amount of industrial waste production generated by the massive industry and the activities of workers who work in the industry also affect the disposal of domestic industrial waste generated by industry. A high COD value will result in reduced oxygen content in the body of water so that it disrupts aquatic ecosystems.

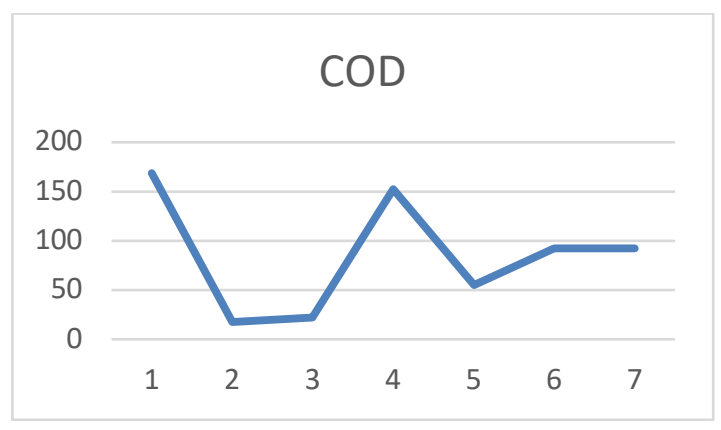

Fig. 3. COD Concentration Graphic

\subsubsection{TSS Concentration}

Based on the TSS test data, it can be seen that TSS concentrations meet the quality stones at all sample points. The highest yield is at sample point 1 , which is located at the PT. ABC with a value of $2 \mathrm{mg} / 1$ and the lowest point is at sample points $3 \& 7$, before the outlet of PT. DEF and after PT. GHI with a value of $1.1 \mathrm{mg} / 1$. 


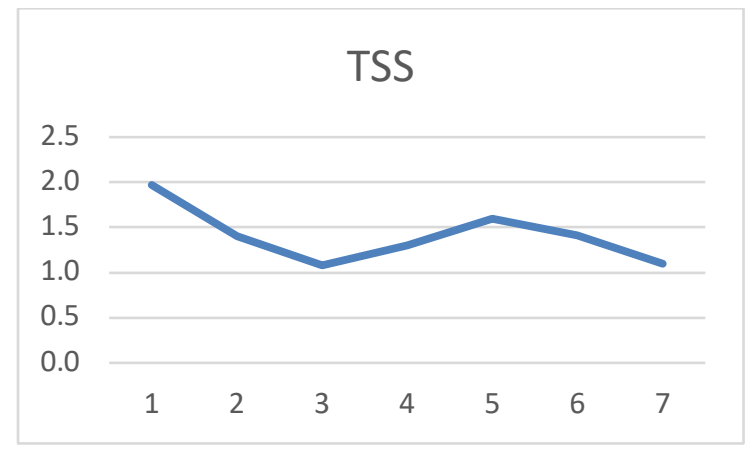

Fig. 4. TSS Concentration Graphic

\subsection{Klampok River Quality Modeling with QUAL2KW Software}

QUAL2KW is a river water quality modeling program, which is an update of QUAL2E. This model can simulate the transport of various pollutants in river water [17]. The purpose of using a model is to simplify an event so that the behavior of the incident can be known. In QUAL2KW conditions can be known along the river, so that further action can be taken as industries that exist along the river are only allowed to dispose of their waste at specific loads.

\section{Model Calibration}

Model calibration is carried out with the aim that the model's water quality data approaches the input data that has been entered into the program. Water quality data entered is water quality data results from the analysis in the laboratory. In the calibration of river water quality data, the data to be adjusted is the data in the Reach Rates sheet, where the data in the sheet is carried out trial and error so that the model water quality data approaches the existing water quality data. Model calibration in QUAL2KW is divided into 2, namely calibration of hydraulic data and calibration of water quality data. Before calibrating water quality data, calibration of river hydraulics data in the Hydraulics Datasheet contains data on the distance, flow, depth, velocity, and the actual width of the river. After that, river water quality data is calibrated in each segment. In water quality calibration, the data inputted is the data in the WQ Datasheet, Diffuse Source (water quality data), as well as other supporting data such as water temperature, dew point temperature, wind speed, cloud cover, shade, and solar. When performing calibration of river quality, the data to be changed so that the water quality of the model approaches the actual water quality is the data in the Reach Rates sheet, where the values in the sheet are carried out trial and error on each parameter coefficient.

The graph of the results of running before and after the input from the industry is as shown below: 


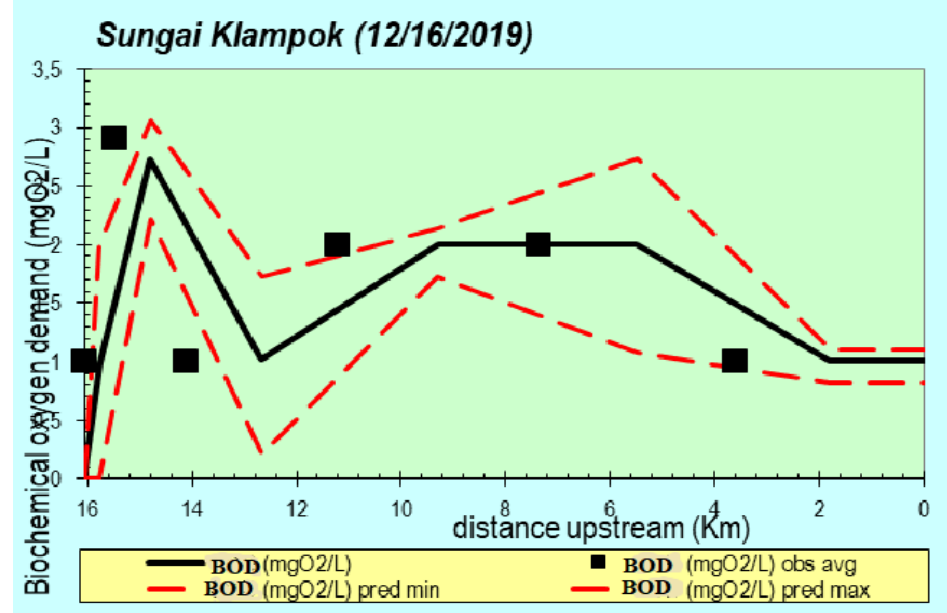

Fig. 5. Running Results Chart QUAL2KW BOD Parameters Before Industrial Input

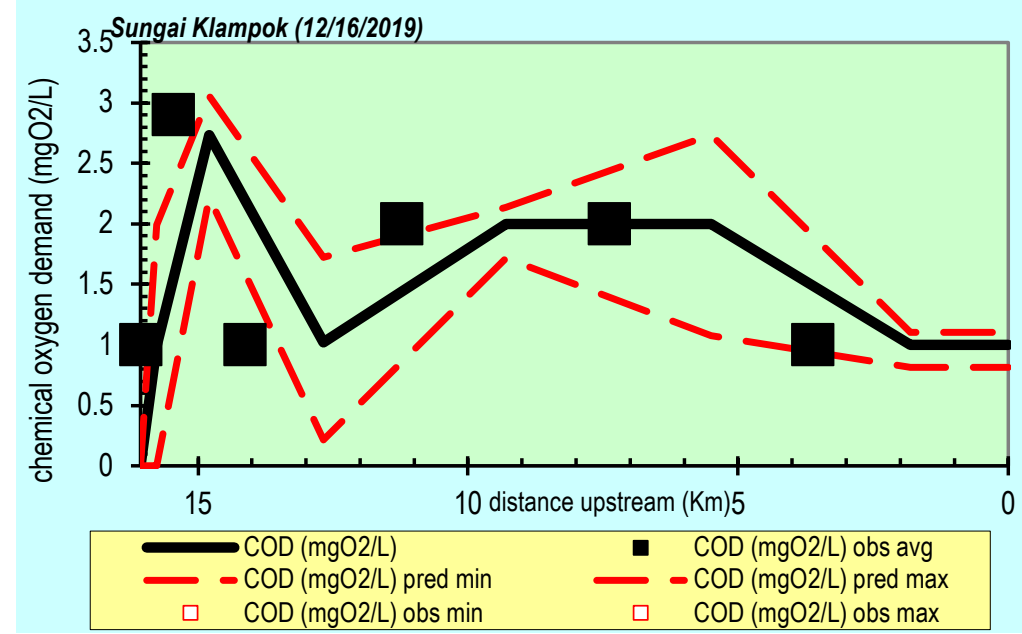

Fig. 6. Running Results Chart QUAL2KW BOD Parameters After Industrial Input

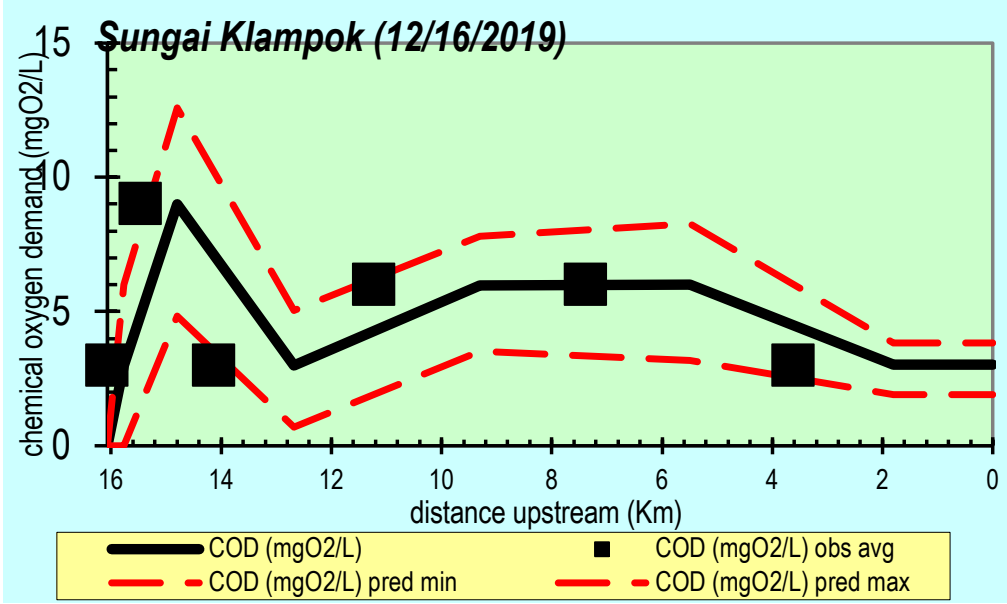


Fig. 7. Running Results Chart QUAL2KW COD Parameters Before Industrial Input

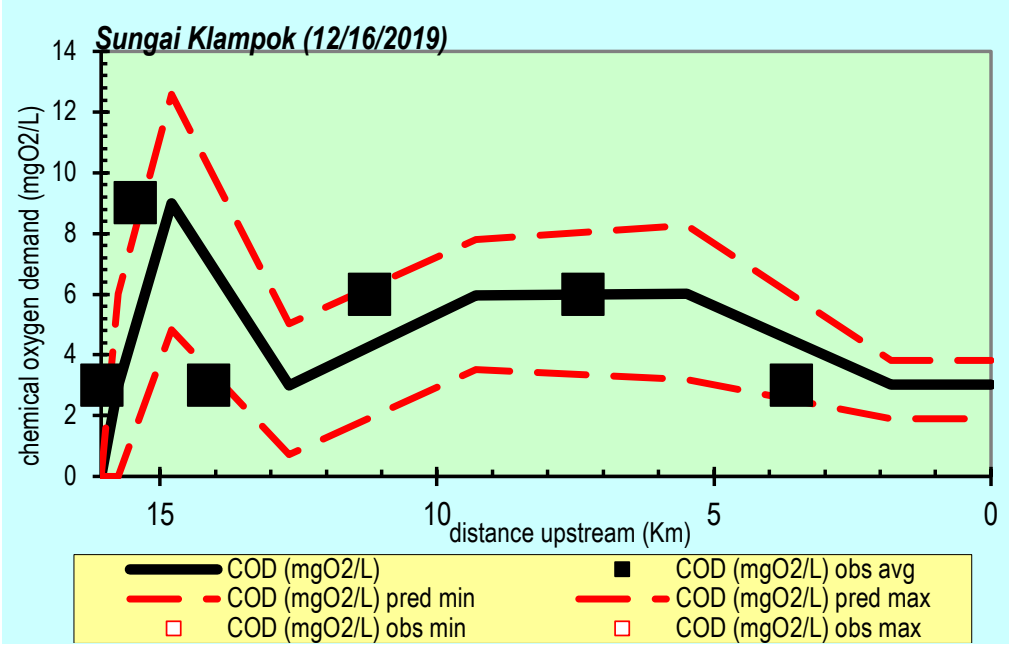

Fig. 8. Running Results Chart QUAL2KW COD Parameters After Industrial Input

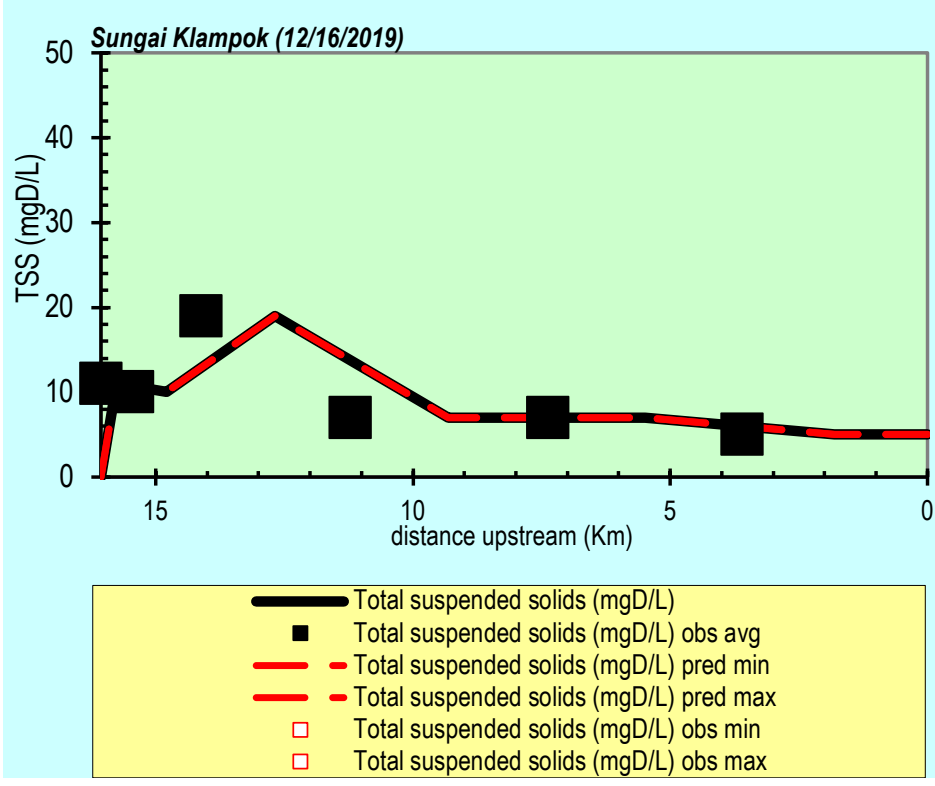

Fig. 9. Running Results Chart QUAL2KW TSS Parameters Before Industrial Input 


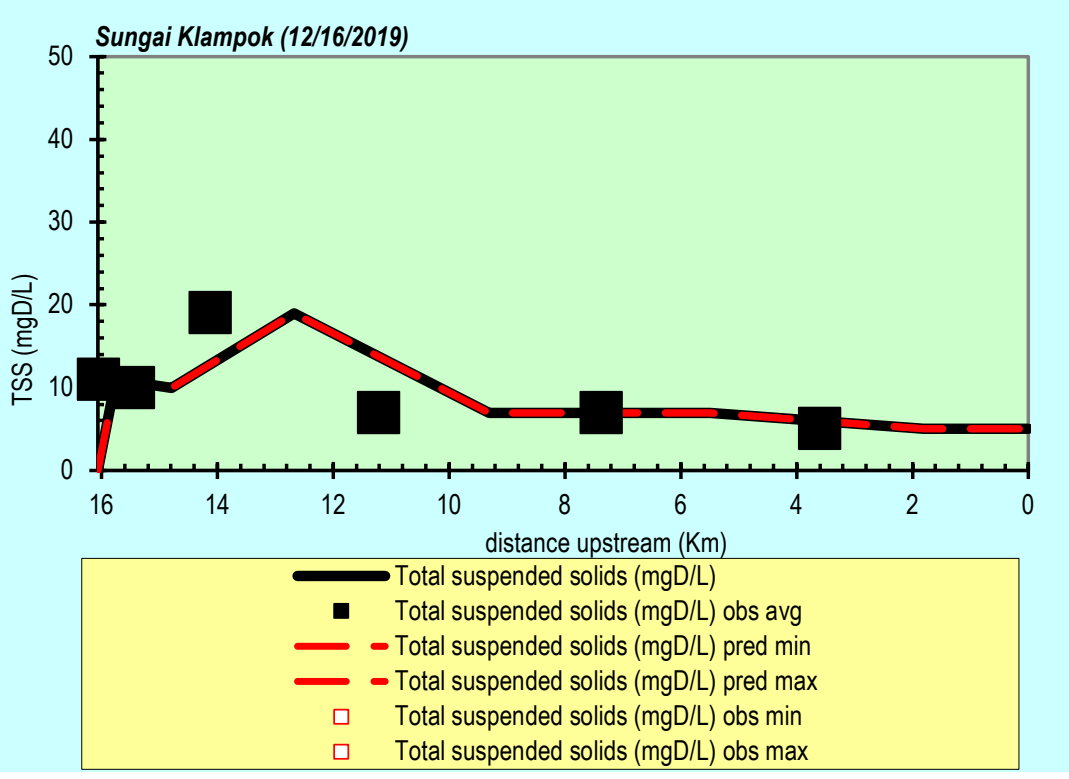

Fig. 10. Running Results Chart QUAL2KW TSS Parameters After Industrial Input

\section{Conclusions and Recommendations}

\subsection{Conclusions}

Based on the results of research and discussion, then from this study, it can be concluded that:

1. Production wastewater and domestic wastewater generated by industrial activities around the Klampok River contribute to the actual pollution burden on the Klampok River, affecting the value of the BOD, COD, and TSS parameters. This pollution load affects the water quality of the Klampok River as follows:

In general, there is an increase in the concentration of all parameters from the initial sampling point (sampling point 1) to the last sampling point (sampling point 7).

a. For the BOD parameter quality standard, the addition of pollutant load from industrial outlets causes the BOD value to increase until the last sampling point. After receiving input from industrial outlet 1 of $1.62 \mathrm{mg} / 1$ (sampling point 1 ), the BOD value increases to $2.46 \mathrm{mg} / 1$ (sampling point 2 ). At sampling point 3 , the BOD value was $1.93 \mathrm{mg} / 1$ after receiving input from industrial outlets 2 of $1.97 \mathrm{mg}$ $/ 1$, the BOD value increased significantly to $3.33 \mathrm{mg} / 1$ (sampling point 5). At sampling point 7 (final sampling point), the BOD value was $3.86 \mathrm{mg} / 1$ after receiving input from industrial outlet three at $2.61 \mathrm{mg} / 1$. This indicates that the Klampok River does not have the capacity to increase the BOD pollutant load in classes I and II. Other factors causing high BOD parameters include input from domestic waste, as well as runoff from agricultural activities and residential waste generated in segment 5 of the Klampok River and previous inputs from segment 1segment 4 both from domestic waste and agricultural waste.

b. The COD parameter, after receiving input from industrial outlet 1 is $168.7 \mathrm{mg} / 1$ (sampling point 1), the COD value becomes $17.5 \mathrm{mg} / 1$ (sampling point 2). At sampling point 3, the COD value was $22 \mathrm{mg} / 1$ after receiving input from industrial outlets 2 of $152 \mathrm{mg} / 1$, the COD value increased significantly to $55.3 \mathrm{mg} / 1$ 
(sampling point 5). At sampling point 7 (final sampling point), the COD value was $92 \mathrm{mg} / 1$ after receiving input from industrial outlet three at $92 \mathrm{mg} / 1$. This indicates that the Klampok River no longer has the capacity to increase the burden of COD pollutants in classes I and II. Other factors causing high COD parameters include inputs from domestic waste, as well as runoff from agricultural activities and residential waste generated in segment 5 of the Klampok River and previous inputs from segment 1 -segment 4 both from domestic waste and agricultural waste.

c. For TSS parameter quality standards, the addition of pollutant load from industrial outlets does not significantly influence. At sampling point 1 , which is an industrial outlet one the value of TSS is $2 \mathrm{mg} / 1$, after receiving input from industrial outlet 1 , the value of TSS becomes $2.2 \mathrm{mg} / 1$. At sampling point 3, the value of TSS was 1.1 $\mathrm{mg} / 1$ after receiving input from industrial outlets 2 of $1.3 \mathrm{mg} / 1$, (sampling point 4), the TSS value increased to $1.6 \mathrm{mg} / 1$. At sampling point 7 , the value of TSS was 1.1 $\mathrm{mg} / 1$ after receiving input from industrial outlets 3 of $1.4 \mathrm{mg} / 1$, (sampling point 6). This indicates that the Klampok River still has the capacity to increase the burden of TSS pollutants in class II.

2. Based on the analysis of the impact of industrial activities operating around the Klampok River on parameters of river water quality pollution, namely BOD, COD, and TSS, control of Klampok River water quality pollution results in recommendations for controlling water pollution in the Klampok River, namely, the study of class determination Klampok River water and capacity according to its purpose, increasing the frequency of monitoring and monitoring of industrial activities operating around the Klampok River, increasing the number of monitoring points and monitoring frequency of Klampok River water quality, as well as law enforcement and local rewards to industries in environmental management.

\subsection{Recommendations}

Based on the results of research and discussion and conclusions, the suggestions that can be submitted are as follows :

1. It is necessary to conduct monitoring of the water quality of the Klampok River, a minimum of 2 monitoring points namely upstream and downstream, increasing the frequency of monitoring to a minimum of 2 times a year, i.e., in the rainy season and the dry season by using an accredited laboratory in order to obtain the results of the Klampok River water quality measurement accurate.

2. The more detailed inventory of pollution sources related to pollutant sources produced by industries operating around the Klampok River needs to dispose of their waste into the Klampok River so that the results of the QUAL2KW modeling can be closer to the actual value.

3. The need for further teaching related to QUAL2KW software in the course of Environmental Quality Management or Modeling and Programming in the Department of Environmental Engineering to increase the skills of Environmental Engineering students regarding river water quality modeling.

4. Further research is needed regarding the capacity of the pollution load of the Klampok River that has been polluted by waste generated by industrial activities operating around the Klampok River for other parameters.

\section{References}

1. Alaerts, G dan S. S. Santika. 1984. Metoda Penelitian Air. Surabaya: Penerbit Usaha Nasional. 
2. Anggriawan, Rezananda. 2018. Penentuan Daya Tampung Beban Cemaran Senyawa Nitrit dan Nitrat Menggunakan Program QUAL2E Studi Kasus: Sungai Klampok, Kabupaten Semarang, Jawa Tengah (Skripsi). Departemen Teknik Lingkungan. Universitas Diponegoro, Semarang.

3. Asdak, Chay. 2007. Hidrologi dan Pengelolaan Daerah Aliran Sungai. Gadjah Mada University Press, Yogyakarta.

4. Asdak, Chay. 2010. Hidrologi dan Pengelolaan Daerah Aliran Sungai, Cetakan ke 5, Yogyakarta: Gadjah Mada University Press.

5. Direktorat Kehutanan dan Konservasi Sumberdaya Air. 2008. Kajian Model Pengelolaan Daerah Aliran Sungai (DAS) Terpadu. Jakarta: Departemen Kehutanan

6. Effendi, H. 2000. Telaah Kualitas Air Bagi Pengelolaan Sumberdaya dan Lingkungan Perairan. Kanisius. Yogyakarta.

7. Effendi, Hefni. 2003. Telaah Kualitas Air Bagi Pengelolaan Sumber Daya dan Lingkungan Perairan. Yogyakarta: Kanisius.

8. Fardiaz, Srikandi. 1992. Polusi Air dan Udara. Yogyakarta: Kanisius.

9. Ginting, P., 2008. Sistem Pengelolaan Lingkungan dan Limbah Industri, CV. Yrama Widya, Bandung.

10. Haqi, F. B. 2013. Karakteristik Self Purification Sungai Celeng Kecamatan Imogiri Kabupaten Bantul, Universitas Gadjah Mada, Yogyakarta.

11. Kirchman, D.L. 2000. Microbial Ecology of Ocean. Wiley-Liss. A John and Sons, Inc. New York.

12. Kodoatie, R.J. dan Sugiyanto, 2002. Banjir, Beberapa Penyebab dan Metode Pengendaliannya dalam Perspektif Lingkungan, Pustaka Pelajar, Yogyakarta.

13. Kordi, M.G., Tancung, A.B., 2007, Pengelolaan Kualitas Air dalam Budidaya Perairan, PT. Ineka Cipta, Jakarta.

14. Mara, Duncan. 2009. Domestic Wastewater Treatment in Developing Country. London: Earthscan.

15. Metcalf dan Eddy., 1991. Wastewater Engineering: Treatment, Disposal, and Reuse. Mc Graw Hill Book Co. Singapore.

16. Mihelcic, James. R et al. 2009. Field Guide To Environmental Engieering for Development Workers. Water, Sanitation, and Indoor Air. Virginia: American Society of Civil Engineering.

17. Pelletier, Greogory J, Steven C. Chapra, Hua Tao. 2006. Qual2Kw - A Framework for Modelling Water Quality In Streams and Rivers Using A Genetic Algorithm for Calibration. Vol 2 (2006). Elsevier. https://doi.person/10.1016/j.envsoft.2005.07.002.

18. Republik Indonesia. 2001. Peraturan Pemerintah Republik Indonesia Nomor 37 Tahun 2012 tentang Pengelolaan Daerah Aliran Sungai. Sekretariat Negara. Jakarta.

19. Republik Indonesia. 2001. Peraturan Pemerintah Republik Indonesia Nomor 82 Tahun 2001 tentang Pengelolaan Kualitas Air dan Pengendalian Pencemaran Air. Sekretariat Negara. Jakarta.

20. Republik Indonesia. 2009. Undang-Undang Republik Indonesia Nomor 32 Tahun 2009 tentang Pengelolaan dan Perlindungan Lingkungan Hidup. Sekretariat Negara. Jakarta.

21. Republik Indonesia. 2010. Peraturan Menteri Lingkungan Hidup Republik Indonesia Nomor 01 Tahun 2010 tentang Tata Laksana Pengendalian Pencemaran Air. Sekretariat Negara. Jakarta.

22. Sastrawijaya, A. T. 1991. Pencemaran Lingkungan. Rineka Cipta. Jakarta.

23. SNI 6989: 2008. Air dan Air Limbah Bagian 57 tentang Metoda Pengambilan Contoh Air Permukaan. Badan Standardisasi Nasional.

24. Sunu, P. 2001. Melindungi Lingkungan dengan Menerapkan ISO 14001. Jakarta: PT. Grasindo. 
25. Suripin, 2002. Pelestarian Sumber Daya Tanah dan Air, Penerbit Andi, Yogyakarta.

26. Triatmodjo, Bambang. 2010. Hidrologi Terapan. Yogyakarta: Beta Offset.

27. Wardhana, W.A., 2004. Dampak Pencemaran Lingkungan Edisi 4, Penerbit Andi, Yogyakarta 